\title{
Determination of Morphometric and Genetic Structure in Salmo Populations Inhabiting Samsun Province: A New Record for Black Sea Region
}

\author{
Savaş YILMAZ Melek OZPICAK* Semra SAYGIN Nazmi POLAT \\ Ondokuz Mayis University, Arts and Sciences Faculty, Biology Department, Samsun, Turkey
}

How to cite: Yilmaz, S., Ozpicak, M., Saygin, S. \& Polat, N. (2021). Determination of Morphometric and Genetic Structure in Salmo Populations Inhabiting Samsun Province: A New Record for Black Sea Region. J. Anatolian Env. and Anim. Sciences, 6(4), 765-773.

Atıf yapmak için: Yılmaz, S., Özpiçak, M., Saygın, S. \& Polat, N. (2021). Samsun Bölgesi'nde Yaşayan Salmo Populasyonlarının Genetik ve Morfometrik Yapısının Belirlenmesi: Karadeniz Bölgesi için Yeni Bir Kayıt. Anadolu Çev. ve Hay. Dergisi, 6(4), 765-773.

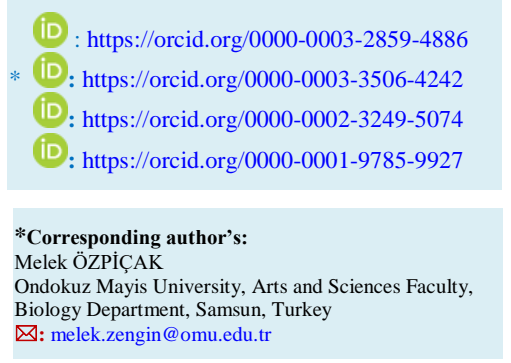

\begin{abstract}
This study aimed to determine genetic and morphometric characteristics of trout population in Terme Stream, a southern coastal Black Sea drainage. A total of 50 samples were used in morphometric studies and 29 traditional morphometric measurements were taken from all samples with a digital caliper. In addition to morphometric evaluations, mtDNA (cyt b and Control region), and nDNA (Gh2c1) markers were used in molecular studies, too. For molecular studies, DNA was extracted from caudal fin tissue of 10 samples. A total of $991 \mathrm{bp}$ long consensus length of cyt b gene, $974 \mathrm{bp}$ of Control Region and 538 bp of Gh2c1 were obtained (the accession numbers MW871594 for cyt b, MZ055401for Control Region, and MZ055402 for Gh2c1). However, Salmo species from the GenBank database, and also Salmo salar (LC012541-outgroup) were used in phylogenetic analyses. According to the results of this study, a new record, Salmo fahrettini, from Black Sea Region (Terme-Salıpazarı) were described with molecular and morphometric analysis.
\end{abstract}

Keywords: Black Sea, mtDNA, morphometric, nDNA, Salmo fahrettini.

\section{Samsun Bölgesi’nde Yaşayan Salmo Populasyonlarının Genetik ve Morfometrik Yapısının Belirlenmesi: Karadeniz Bölgesi için Yeni Bir Kayıt}

*Sorumlu yazar:

Melek ÖZPIÇAK

Ondokuz Mayıs Üniversitesi, Fen Edebiyat

Fakültesi, Samsun, Türkiye

凶: melek.zengin@omu.edu.tr

\begin{abstract}
Öz: Bu çalışmada, Güney Karadeniz'in kıyısal bir drenajı olan Terme Deresi’ndeki doğal alabalık populasyonunun genetik ve morfometrik özelliklerinin belirlenmesi amaçlanmıştır. Toplamda 50 örnek morfometrik analizlerde kullanılmıştır ve dijital kumpas kullanılarak örneklerden 31 adet geleneksel morfometrik ölçüm alınmıştır. Morfometrik değerlendirmelere ilave olarak mtDNA (cyt b ve Kontrol Bölgesi) ve nDNA (Gh2c1) gen bölgeleri moleküler çalışmalarda kullanılmıştır. Moleküler çalışmalar için 10 adet örneğin kaudal yüzgeç dokularından DNA elde edilmiştir. Cyt b gen bölgesinin 991 bazlık, Kontrol Bölgesi'nin 974 ve Gh2c1 gen bölgesinin 538 baz çiftlik kısmı elde edilmiştir (Erişim numaraları: MW871594-cyt b, MZ055401-Kontrol Bölgesi ve MZ055402-Gh2c1 bölgesi). Ayrıca GenBank veri tabanından alınmış olan Salmo türleri ile Salmo salar (LC012541-Dış grup) filogenetik analizlerde kullanılmıştır. Bu çalışmadan elde edilen sonuçlara göre Karadeniz Bölgesi için yeni bir kayıt olan Salmo fahrettini moleküler ve morfometrik analizler ile tanımlanmıştır.
\end{abstract}

Anahtar kelimeler: Karadeniz, mtDNA, morfometrik, nDNA, Salmo fahrettini.

\section{INTRODUCTION}

The basis of all biological studies is based on systematic and taxonomy. It is essential to correctly determine the systematic position of the species for the studies to be carried out. Since the beginning of Linnaean taxonomy, taxonomists have started describing and classifying species, mainly based on morphological characters (Tougard et al., 2018). For more than a century, scientists have tried to reveal diversity by examining the internal and external morphologies of species. In recent years with the developing technology, classical systematic is been supported by molecular studies (Sušnik et al., 2006; Turan et al., 2009; Mangit \& Yerli, 2018; Ninua et al., 2018; Özpiçak \& Polat, 2019; Bektas et al., 2020; Delling et al., 2020). Genetic techniques in fisheries science have revealed that many phenotypically different populations or genera are not genetically different.

It is much debated to determine the causes of phenotypic variations among populations of the same 
species in terms of fisheries management and biology (Cadrin, 2000). For this reason, morphometric studies need to support with different approaches like molecular techniques. Population genetic bottleneck, geographic isolation, living environment, gene flow, and natural selection have large effects on the genetic construction of populations ( $\mathrm{Li}$ et al., 2007). It is known that especially biogeography has a critical role in the formation of genetic isolation mechanisms. The distribution of biological diversity in the world is usually measured as the diversity of species. However, subspecies are formed mostly due to geographical isolation within the species and genetic studies have made a great contribution to subspecies diversity (Hewitt, 2004). Especially natural trout show lots of variations in this respect. These variations observed within the species confuse the studies performed.

The evolutionary relations of brown trout have been studied with molecular techniques throughout its natural range of distribution (Bernatchez, 2001). Genus Salmo has been divided into five main evolutionary lineages by evaluating molecular studies. These linages have been described as Atlantic (AT), Mediterranean (ME), Marble (MA), Adriatic (AD), and Danubian (DA) by Bernatchez et al. (1992). The Black Sea Basin is accepted as the ancestral center of the Danubian lineage.

Genus Salmo is distributed throughout Europe, reaching southwards in Africa to Morocco (Algeria) and eastwards to the upper Amu Darya drainage in Afghanistan (Kottelat, 1997). The fact that Anatolia is a speciation center due to its geological and geomorphological location has led to the observation of many taxonomic studies on Salmo species. The taxonomy of brown trout is still controversial. According to the literature 16 trout species described inhabiting Turkey (Turan et al., 2009; Turan et al., 2014a; Turan et al., 2014b; Turan et al., 2017; Turan et al., 2020; Turan \& Bayçelebi, 2020; Çiçek et al., 2020; Turan \& Aksu, 2021; Turan et al., 2021). Despite the presence of these species in almost all cold streams and rivers in Turkey, due to their economic importance, overfishing has caused a serious decline in populations.

The aim of this study is (i) to describe trout population according to updated literature and (ii) discuss the Salmo diversity with molecular (mtDNA and nDNA) and morphological data in Terme Stream.

\section{MATERIALS AND METHODS}

Study Area and Sampling: Terme Stream is located by the east of Samsun in the Central Black Sea region (Turkey). It is formed by the merging of Yeşilköy, Ayazma and Çağlayan streams which was born from the northern slopes (1100-1300 m) of the Canik Mountains
(Uncu, 1995). A total of 50 individuals were collected in Terme Stream (in Salıpazar1) with an electroshocker (Figure 1).

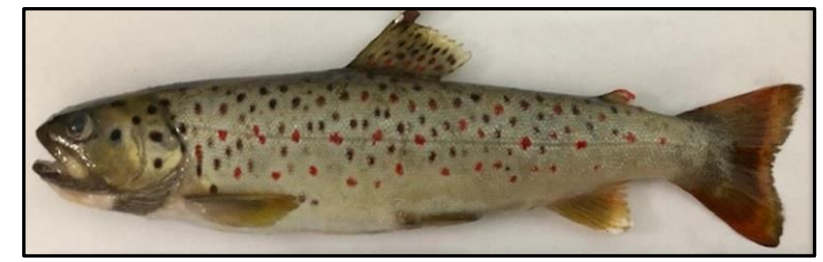

Figure 1. Salmo fahrettini (Terme Stream, 199 mm SL)

After anesthesia, samples were transferred to the laboratory for morphological and molecular investigations. Identification of the specimens was conducted following literature (Kottelat \& Freyhof, 2007; Turan et al., 2020). Additionally, morphological measurements were taken from samples according to literature (Kottelat \& Freyhof, 2007; Delling et al., 2020). The care and use of experimental animals, sampling and analysis techniques used in this work are approved by Ondokuz Mayis University Animal Experiments Local Ethics Committee with decree no "2017/38".

Molecular methods: In this study 10 samples were used in genetic analysis. Caudal fin clips of each sample were conserved in $98 \%$ ethanol and stored at $-20^{\circ} \mathrm{C}$ until DNA extraction. Total genomic DNA was extracted from 15-20 mg of caudal fin tissue by the INVITROGEN, PureLinkTM Genomic DNA Tissue Kit using the following the manufacturer's protocol.

Partial fragments of the cyt $b$, Control region and Gh2c1 were amplified by PCR using the following primers; 5'-CATAATTCCTGCTCGGACTTTAACC-3' and 5'-TTTAACCTCCGACCTCCGGTTTACA-3' for cyt b (Crête-Lafrenière et al., 2012); 5'CCCAAAGCTAAAATTCTAAAT-3' and 5'GCTTTAGTTAAGCTACGC-3' for Control region (Cortey \& García-Marín, 2002); 5'ATCGTGAGCCCAATCGACAAGCAG-3' and 5'GGGTACTCCCAGGATTCAATCAGG-3' for Gh2c1 (Von Schalburg et al., 2008).

The PCR conditions were an initial denaturation $\left(95^{\circ} \mathrm{C}, 5 \mathrm{~min}\right.$ for Control Region and cyt b; $94{ }^{\circ} \mathrm{C}, 3 \mathrm{~min}$ for $\mathrm{Gh} 2 \mathrm{c} 1$ ) followed by 35 cycles of strand denaturation (95 ${ }^{\circ} \mathrm{C}, 1 \mathrm{~min}$ for Control Region; $95^{\circ} \mathrm{C}, 40 \mathrm{sec}$ for cyt b; $94{ }^{\circ} \mathrm{C}, 1 \mathrm{~min}$ and $30 \mathrm{sec}$ for $\left.\mathrm{Gh} 2 \mathrm{c} 1\right)$, annealing $\left(52{ }^{\circ} \mathrm{C}, 1\right.$ min for Control Region, $51{ }^{\circ} \mathrm{C}, 40 \mathrm{sec}$ for cyt b; $55^{\circ} \mathrm{C}, 2$ min for $\mathrm{Gh} 2 \mathrm{c} 1)$ and DNA extension $\left(72{ }^{\circ} \mathrm{C}, 1 \mathrm{~min}\right.$ (Control Region), $2 \mathrm{~min}$ (cyt b), $3 \mathrm{~min}(\mathrm{Gh} 2 \mathrm{c} 1)$ ), then final extension $\left(72{ }^{\circ} \mathrm{C}, 10 \mathrm{~min}\right)$. PCR products were visualized in $1.5 \%$ agarose low-melting point gels stained with ethidium bromide for band characterization via ultraviolet 
transillumination. Sequencing was performed directly using the corresponding both forward and reverse PCR primers. Sequence analysis was carried out at the Macrogen sequencing service. Sequences were deposited in GenBank.

Nucleotide sequences were aligned with BioEdit (Hall, 1999) software. mtDNA and nDNA regions were analyzed to determine the nucleotide composition for Salmo population using MEGA 5 (Tamura et al., 2011). DnaSP v.5.10 were used to calculate the number of haplotypes $(\mathrm{H})$, haplotype diversity $(h)$, nucleotide diversity $(\pi)$, and the average number of nucleotide substitutions (K) (Librado \& Rozas, 2009). The best fit models of nucleotide substitution for cyt $b$, Control Region and Gh2c1 were calculated by the Akaike (AIC) and Bayesian Information Criteria (BIC) approaches in the $\mathrm{j}$ Model Test 0.1.1 (Posada, 2008). ML trees were used to determine phylogenetic relationships between species. In addition, evaluations were carried out for the cyt $b$ region. ML analyses were performed using PhyML version 3.0 (Guindon \& Gascuel, 2003) and using the best-fit models (TIM3+I for cyt b). ML tree was generated using 1000 bootstrap replicates to explore phylogenetic affinities of the mitochondrial lineages. Phylogenetic trees were drawn using TREEVIEW v.1.6.6 (taxonomy.zoology.gla.ac.uk/rod/treeview.html).

Phylogenetic relationships were inferred using different analytical approaches, performed with PAUP version 4.0b10 (Swofford, 2003) and PHYLIP v.3.68 (Felsenstein, 1993). Maximum parsimony (MP) analysis was conducted assuming equal weightings for all characters. SplitsTree (Huson and Bryant, 2006) were used to determine the relationships between haplotypes as another approach. Salmo species from the GenBank database and Salmo salar (LC012541-outgroup) were used in analyses.

Morphological methods: After sampling, all samples were brought to Ondokuz Mayis Ichthyological Research Laboratory for investigations. A total of 29 traditional morphometric measurements were taken from all samples. All measurements were taken on the left side of each specimen with a digital caliper by the same person according to Delling et al. (2020), and Kottelat and Freyhof (2007) $( \pm 0.1 \mathrm{~mm})$. The number of scales along the lateral line to the end of the caudal peduncle (left side), gill rakers, number of fin rays were counted under a binocular microscope because of determining descriptive characteristics according to literature.

All the variables were tested for normality and homogeneity of variance using the Kolmogorov-Smirnov, Shapiro and Levene's test respectively. Length and weight relations were determined by using the equation of Bagenal and Tesch (1978). Additionally, the t-test employed to test whether the slopes $(b)$ were significantly different from 3 , indicating the growth type: isometric $(b=3)$, positive allometric $(b>3)$ or negative allometric $(b<3)$. According to the measurements taken from the species, relationships of morphometric characters with total length and regression relations were calculated, measurements taken on the head were related to the head length. All the calculations were done using SPSS 21, Minitab 17.0 and the Excel software, and results were considered as significant for $\mathrm{P}<0.05$.

\section{RESULTS}

Molecular results: In the present study, the total of 991 bp long consensus length of cyt b gene, 974 bp of Control Region and 538 bp of Gh2c1 were aligned and analyzed to determine the genetic variation. For each of the regions only one haplotype is determined. Haplotypes were recorded in GenBank database with Accession numbers MW871594 for cyt b, MZ055401 for Control Region, and MZ055402 for Gh2c1.

Average nucleotide composition of adenine (A), thymine $(\mathrm{T})$, cytosine $(\mathrm{C})$, guanine $(\mathrm{G})$ of cyt b were examined as $24.54 \%, 28.84 \%, 31.13 \%$ and $15.49 \%$, respectively. Haplotype diversity (h) and nucleotide diversity $(\pi)$ were calculated as $h=0.808$ and $\pi=0.0330$. GenBank haplotype sequences are used as a reference and illustrating the diversity on all the range of the Salmo species. A comprehensive network of these new and published haplotypes is presented in Figure 3. For cyt b, pairwise sequence divergence (K2P) among species of Salmo species analyzed ranged from $0.00 \%$ (between Salmo fahrettini and Salmo sp. (Terme population)) to $6.58 \%$ (S. salar and S. euphrataeus). Based on the Kimura 2-parameter (K2P), overall genetic distance between Salmo species is $1.67 \%$. The Control Region dataset had an aligned length of $974 \mathrm{bp}$. Average nucleotide composition of adenine (A), thymine (T), cytosine $(\mathrm{C})$, guanine $(\mathrm{G})$ of Control Region were examined as $30.90 \%, 31.62 \%$, $23.00 \%$ and $14.48 \%$, respectively. The growth hormone dataset had an aligned length of $538 \mathrm{bp}$. The Average nucleotide composition of adenine (A), thymine (T), cytosine $(\mathrm{C})$, guanine $(\mathrm{G})$ of $\mathrm{Gh} 2 \mathrm{c} 1$ were examined as $31.93 \%, 28.25 \%, 22.12 \%$, and $17.70 \%$, respectively. According to ML analyses (sequences from GenBank database and data form present study were used), Salmo sp. population in Samsun is described as Salmo fahrettini, a new record for this province (Figure 2-Figure 3). Phylogenetic trees were drawn based on the cyt $b$ gene region, as studies on Gh2c1 and the Control Region are limited in the literature. 


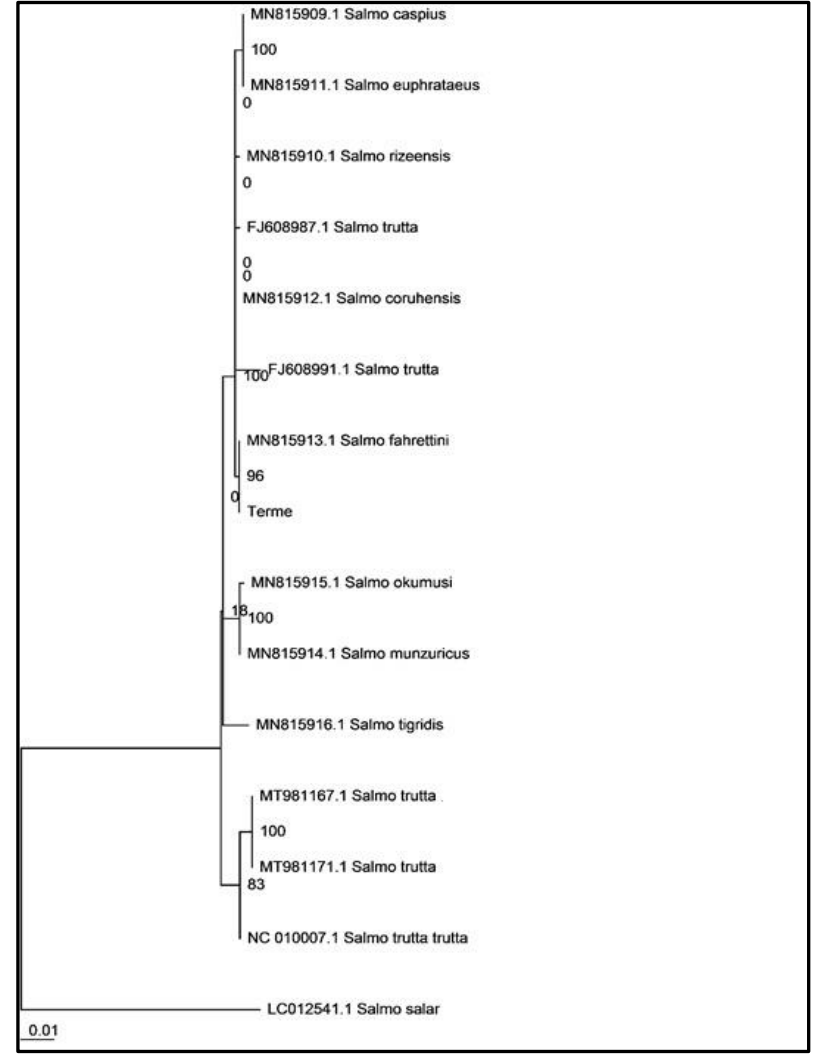

Figure 2. Maximum likelihood (ML) tree based on mitochondrial cytochrome b gene sequences of Salmo species in Terme Stream and Genbank data. Bootstrap values are shown above nodes on tree if $50 \%$ or higher.
Morphological results: The minimum and maximum total lengths and weights of the samples are 6.3$24.1 \mathrm{~cm}$ and 2.73-162.51 g, respectively. The morphometric measurements were offered in Table 1.

Length-weight relationship were calculated as $\mathrm{W}=0.009 \mathrm{TL}^{3.078}\left(\mathrm{r}^{2}=0.992\right)$. Analyses showed that Salmo sp. has isometric growth in Terme population (95\% CI of $b=2.997-3.159$ ) (CI: Confidence intervals). All of the morphometric measurement has significant correlation with the total length after $M$ transformation indicating that allometric formula was effective in removing size effect from the data $(\mathrm{P}<0.001)$. Relationships between total length and morphometric characteristics were calculated with linear regression (Table 2) and measurements taken from head were related to head length.

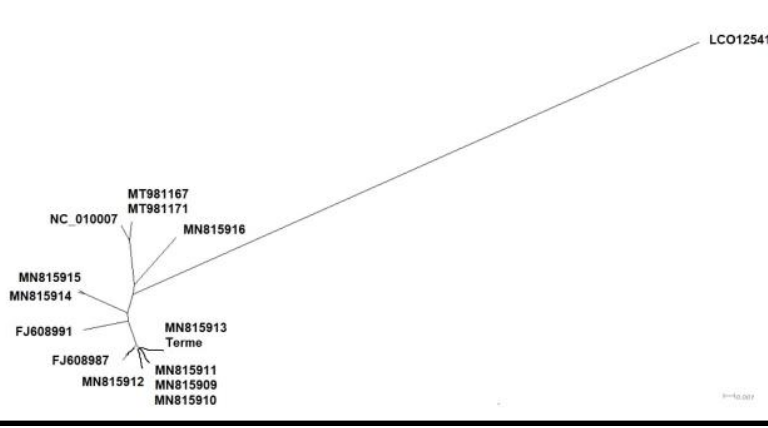

Figure 3. The tree model created using the SplitsTree program for the cyt $\mathrm{b}$ gene region with haplotypes and outgroup (LC012541.1-Salmo salar).

Table 1. Morphometric data of trout population from Terme Stream

\begin{tabular}{|c|c|c|c|c|c|c|c|}
\hline Gender & Male & Male & & Female & & Undetermined & \\
\hline Number of specimens & Holotype & $\mathrm{N}=8$ & & $\mathrm{~N}=10$ & & $\mathrm{~N}=31$ & \\
\hline Standard length $(\mathrm{mm})$ & 199 & $83-159$ & S.D. & $74-144$ & S.D & $49-89$ & S.D \\
\hline \multicolumn{8}{|l|}{ Percentages of standard length $(\mathrm{mm})$} \\
\hline Head Length & 25.4 & $25.0-31.0(27.6)$ & 1.9 & $24.3-26.9(25.6)$ & 0.7 & $23.2-29.7(27.2)$ & 1.4 \\
\hline Head Depth & 17.7 & $14.4-18.9(16.7)$ & 1.8 & $14.2-18.1(16.4)$ & 1.4 & $12.8-19.3(16.8)$ & 1.4 \\
\hline Predorsal length & 46.5 & $47.1-51.2(48.9)$ & 0.9 & $46.6-48.8(47.8)$ & 0.7 & $42.1-51.2(48.3)$ & 2.0 \\
\hline Postdorsal length & 51.4 & $47.3-69.1(57.7)$ & 1.2 & $48.9-67.2(58.1)$ & 0.9 & $44.0-69.8(58.8)$ & 2.3 \\
\hline Prepectoral length & 27.0 & $25.2-30.1(27.4)$ & 1.6 & $20.0-27.2(25.2)$ & 2.1 & $22.0-29.9(27.2)$ & 1.4 \\
\hline Postpectoral length & 56.0 & $50.7-59.9(55.8)$ & 2.7 & $50.9-57.5(55.2)$ & 2.0 & $47.9-64.8(54.7)$ & 2.4 \\
\hline Height of dorsal fin & 14.8 & $14.6-18.3(16.0)$ & 1.3 & $12.0-17.0(14.7)$ & 1.4 & $11.9-22.3(16.4)$ & 2.1 \\
\hline Body depth of dorsal fin orgin & 14.8 & $13.2-15.3(14.1)$ & 0.7 & $12.0-16.5(13.6)$ & 1.5 & $10.9-19.8(13.9)$ & 1.6 \\
\hline Length of pectoral fin & 16.3 & $18.5-19.7(19.1)$ & 0.4 & $15.7-20.9(18.5)$ & 1.2 & $17.0-23.9(20.5)$ & 1.3 \\
\hline Length of anal fin base & 9.8 & $9.2-11.2(10.0)$ & 0.6 & $8.8-11.5(9.7)$ & 0.8 & $7.6-12.5(9.6)$ & 1.2 \\
\hline Length of pelvic fin & 12.9 & $13.9-15.7(14.5)$ & 06 & $12.1-151(13.8)$ & 0.9 & $12.2-17.2(15.5)$ & 1.3 \\
\hline Length of upper caudal fin lobe & 20.5 & $19.1-22.8(20.9)$ & 1.3 & $19.1-24.4(21.7)$ & 1.9 & $18.4-25.1(22.0)$ & 1.7 \\
\hline Distance between upper and lower caudal fin lobes & 29.9 & $26.1-30.5(27.9)$ & 1.7 & $25.0-31.1(28.5)$ & 2.1 & $20.5-35.3(28.8)$ & 1.6 \\
\hline Eye diameter & 5.8 & $5.4-7.2(6.5)$ & 0.6 & $5.6-6.7(6.2)$ & 0.3 & $5.3-8.5(7.1)$ & 0.8 \\
\hline Interorbital width & 8.5 & $4.6-8.8(7.4)$ & 1.6 & $5.4-10.2(7.5)$ & 1.5 & $4.5-9.2(7.0)$ & 0.8 \\
\hline Internasal distance & 4.2 & $1.7-4.2(3.1)$ & 0.9 & $2.2-3.9(3.1)$ & 0.5 & $1.3-5.0(3.0)$ & 0.2 \\
\hline Snout length & 4.3 & $3.0-5.7(4.4)$ & 0.9 & $3.4-4.4(3.8)$ & 0.2 & $2.1-4.9(4.1)$ & 0.6 \\
\hline Premaxilla to preoperculum length & 19.7 & $20.0-23.2(21.4)$ & 1.2 & $19.0-20.8(17.8)$ & 0.6 & $17.6-23.9(20.4)$ & 1.3 \\
\hline Distance between dorsal and caudal fin orgin & 35.4 & $35.3-51.9(46.3)$ & 1.2 & $35.4-51.9(44.2)$ & 2.5 & $32.2-55.2(43.9)$ & 2.1 \\
\hline Distance between pectoral and ventral fin & 33.3 & $29.3-32.3(30.8)$ & 1.1 & $29.3-32.9(30.9)$ & 1.1 & 27.8-35.7 (31.3) & 1.8 \\
\hline Distance between ventral and anal fin & 23.3 & $18.0-22.9(20.0)$ & 27 & $18.6-21.8(20.3)$ & 0.9 & $16.5-22.3(19.6)$ & 1.2 \\
\hline Distance between anal and caudal fin & 11.5 & $11.3-24.7(20.9)$ & 1.4 & $11.8-26.4(19.3)$ & 1.6 & $12.8-27.2(19.4)$ & 2.4 \\
\hline Caudal peduncle length & 9.9 & $10.0-12.2(11.5)$ & 0.8 & $11.0-12.7(11.7)$ & 0.4 & $8.0-13.4(11.8)$ & 1.5 \\
\hline Least body depth & 9.6 & $9.1-10.7(9.8)$ & 0.5 & $8.4-10.2(9.5)$ & 1.5 & $7.3-10.8(9.4)$ & 0.8 \\
\hline Maximum body depth & 25.1 & $21.4-25.9(23.3)$ & 1.5 & $8.9-26.2(22.5)$ & 2.5 & $16.0-26.2(22.3)$ & 2.2 \\
\hline Length of adipose fin base & 3.4 & $2.4-4.8(3.4)$ & 0.8 & $2.3-4.8(3.1)$ & 0.7 & $1.7-4.8(3.5)$ & 0.7 \\
\hline
\end{tabular}


Table 2. Morphological characteristics taken from body and total length relationships

\begin{tabular}{|c|c|c|c|c|}
\hline Characteristics & $\mathbf{a}$ & b & $\mathbf{r}^{2}$ & $\mathbf{P}$ \\
\hline Fork length & -0.363 & 0.991 & 0.997 & * \\
\hline Standard length & -0.111 & 0.836 & 0.995 & * \\
\hline Head length & -1.036 & 1.487 & 0.963 & * \\
\hline Head depth & 0.377 & 2.174 & 0.973 & * \\
\hline Predorsal length & -0.865 & 3.985 & 0.993 & * \\
\hline Postdorsal length & 2.325 & 4.546 & 0.903 & * \\
\hline Prepectoral length & 0.017 & 2.211 & 0.973 & * \\
\hline Postpectoral length & -0.911 & 4.633 & 0.979 & * \\
\hline Height of dorsal fin & 1.641 & 1.399 & 0.927 & * \\
\hline Body depth of dorsal fin orgin & -0.806 & 1.230 & 0.965 & * \\
\hline Length of pectoral fin & -0.763 & 0.883 & 0.956 & * \\
\hline Length of anal fin base & 2.794 & 1.334 & 0.969 & * \\
\hline Length of pelvic fin & 1.851 & 1.035 & 0.964 & * \\
\hline Length of upper caudal fin lobe & 1.463 & 1.637 & 0.962 & * \\
\hline $\begin{array}{l}\text { Distance between upper and lower caudal } \\
\text { fin lobes }\end{array}$ & 0.118 & 2.347 & 0.955 & * \\
\hline Eye diameter & 1.064 & 0.449 & 0.917 & * \\
\hline Interorbital width & -0.505 & 0.747 & 0.895 & * \\
\hline Internasal distance & -0.813 & 0.155 & 0.806 & * \\
\hline Snout length & -0.565 & 0.181 & 0.925 & * \\
\hline Premaxilla to preoperculum length & -0.717 & 0.797 & 0.990 & * \\
\hline $\begin{array}{l}\text { Distance between dorsal and caudal fin } \\
\text { orgin }\end{array}$ & 2.881 & 3.365 & 0.818 & * \\
\hline Distance between pectoral and ventral fin & -1.061 & 2.684 & 0.982 & * \\
\hline Distance between ventral and anal fin & -2.302 & 1.884 & 0.970 & * \\
\hline Distance between anal and caudal fin & 4.109 & 1.177 & 0.826 & * \\
\hline Caudal peduncle length & 0.554 & 0.906 & 0.960 & * \\
\hline Least body depth & -0.480 & 0.835 & 0.978 & * \\
\hline Maximum body depth & -2.830 & 2.156 & 0.936 & * \\
\hline Length of adipose fin base & 0.171 & 0.266 & 0.725 & $*$ \\
\hline
\end{tabular}

\section{DISCUSSION AND CONCLUSION}

Salmonids include anadromous and freshwater forms. Because of the economic importance of trouts, overfishing negatively affected Salmo populations. There are many taxonomic studies conducted on the Salmo genus worldwide in the literature (Bernatchez et al., 1992; Cortey \& García-Marín, 2002; Sušnik et al., 2006; Turan et al., 2009; Pustovrh et al., 2014; Splendiani et al., 2019; Segherloo et al., 2021). The combined investigation of genetic and morphological characteristics has allowed the successful recognition of new distinct taxonomic entities in recent years (Ninua et al., 2018; Delling et al., 2020).

Faunistic studies are important for biodiversity and conservation studies. Turkey is a speciation center of different fish species. Important biodiversity hotspots such as Caucasus, Iran-Anatolia and Mediterranean basin exhibit high diversity and endemism for freshwater fish (Perea et al., 2010). One of the most distinctive biogeographical features determining the biodiversity level of Anatolia is the Anatolian diagonal, which is considered to be the biogeographical boundary between the central and eastern Anatolian fauna. In the literature, it is generally accepted that Turkey started to rise in the Middle Miocene, this tectonic uplift continued during the Pliocene (Şengör et al., 1988). During the last interglacial cycle, it is suggested most of the populations or taxa isolated on both sides of the Anatolian diagonal diverged overtime under the influence of environmental factors (Gür, 2016).
Banarescu (1991) suggested that regard the Black and Caspian Sea basins as well as Anatolia as one of the most important refugia for the freshwater species. Since the Salmo species in Turkey may not have been affected by glaciations as much as those in the northern hemisphere, the genetic variability within them was therefore maintained (Bardakci et al., 2006). Studies in recent years have revealed a race for the identification of a species involving Salmo species. Some of the studies that have been carried out are only on morphometry and some are only molecular-based (Turan et al., 2014a; Turan et al., 2017; Tougard et al., 2018). Generally, new species were described in Salmo taxonomy with morphometric observation (Behnke, 1968; Bardakci et al., 1994; Turan et al., 2014b; Turan et al., 2017; Turan \& Bayçelebi, 2020). However, it has been observed that some molecular studies conducted in recent years either support or do not support morphometric studies. Özen (2013) investigated molecular phylogeny of Salmo species in Turkey and stated that ecological forms do not reflect phylogenetic relationships (especially for anadromus or lake forms). Ninua et al., (2018) stated that there was not suitable evidence of the morphological separation between $S$. labrax and $S$. coruhensis. Variations in fish morphology are associated with changes in environment and temperature (Loy et al., 1996; Pakkasmaa and Piironen, 2000), feeding regime and ecological factors such as salinity (Chen et al., 2008), turbidity (Mohadasi et al., 2014) and predation risk (Loy et al., 1996) in their habitats. 
Different gene regions were also used in studies such as cyt b, Control region, COI, microsatellite loci, growth hormone, or vice versa (Berrebi et al., 2019; Rossi et al., 2019; Delling et al., 2020). In this study, cyt b, Control Region and $\mathrm{Gh} 2 \mathrm{c} 1$ regions were used, and phylogenetic evaluations were done with cyt b. Because when the literature is examined, it is seen that the Control Region and nuclear DNA gene regions of Salmo species examined in Turkey have not been studied. For this reason, phylogenetic trees were drawn over the cyt $b$.

Kalayci et al. (2018) suggested that all brown trout populations belonging to the Danubian (DA) lineage (sensu Bernatchez et al., 1992) should have nominotypical species status. Ninua et al. (2018) evaluated the phylogeography, evaluation and taxonomic status of trouts from the Ponto-Caspian drainages. According to the results of their study, southeastern Black Sea area is the most likely place of diversification and species from Black and Caspian Sea drainages are monophyletic. However, salmon taxonomy is still confusing and problematic. In recent years, there are lots of studies about biogeography, phylogeny, phylogeographic and systematic position of Salmo species (Bardakci et al., 2006; Sušnik et al., 2006; Kanjuh et al., 2020; Turan et al., 2020; Guinand et al., 2021). Rossi et al. (2019) investigated the genetic identification of native populations of $S$. trutta complex in central Italy and found that most of the haplotypes observed belong to the Adriatic or Mediterranean lineages. Unfortunately, the fact that the size factor is not eliminated in morphometry-based studies unfortunately causes the identification of erroneous species. In the present study, we can say that species studied which were sequenced with GenBank data were very close together (Figure 2 and Figure 3). According to the result, MN815909-Salmo caspius and MN815911-Salmo euphrataeus and also, MN815915-Salmo okumusi and MN815914-Salmo munzuricus are very close species. It is recommended by us to re-evaluate the genetic results belonging to these species.

Unfortunately, the erroneous approaches in some studies carried out for species identification have brought about literature pollution. Phenotypic plasticity and ecological adaptation have contributed to a confusing nomenclature picture and to "taxonomic inflation" (Tougard et al., 2018). According to Çiçek et al. (2020), there are 16 Salmo species (including S. trutta) in Turkey. However, Turan et al. (2020) reported 14 Salmo species from the inland waters of Turkey. Guinand et al. (2021) indicated that the delimitation of trout taxa by ichthyologists was certainly first impacted by the poor awareness of phenotypic plasticity and speciation as a process, then based on species concepts based on diagnosability, while these taxa are not reproductively isolated and contradict Mayr's (1942) biological species concept.

The last Salmo species which have been described from Erzurum Province: Stream Ömertepesuyu at Palandöken is Salmo fahrettini (Turan et al., 2020) with molecular and morphometric data together and stated that S. fahrettini is most probably endemic to this area. However, in the present study, a new distribution area was determined for $S$. fahrettini. According to the results from present study, samples from Terme Stream (Salıpazarı Province-Samsun) are described as S. fahrettini, too. Molecular results showed that both species ( $S$. fahrettini [Turan et al. (2020)] and samples in this study) were in the same haplotype group and also, there is no differences in sequence results. Additionally, morphological results in present study are similar with Turan et al. (2020) (Table 1).

According to Turan et al. (2009) S. rizeensis lives in the upper part of streams and rivers draining to the south and the southeastern Black Sea and S. coruhensis in the lower and the middle part of the streams and rivers of the same area. Nonetheless, S. fahrettini is described in southeastern Black Sea region. Therefore, it is expected that the trout present in this area will be one of these two species. For this reason, it is very important to know the zoogeographic characteristics and the geological development stages of the studied areas in the conducted studies. Terme Stream is located in the central part of the northern Anatolian Mountain folds, one of Turkey's tectonic units. In the formation of this region in the Quaternary period, the uplifts in the northern Anatolian Mountains and the deposits in the Black Sea basin are very important (Uncu, 1995). Also, Terme Stream was formed by Yeşildere, Ayazma and Kırgıl (Çağlayan) streams, which were born from 1100-1300 m altitudes on the northfacing slopes of Canik Mountains, near Salıpazarı (Uncu, 1995). Therefore, more detailed studies should be done about how the species cross the Anatolian diagonal, northern Anatolian Mountains line and the Canik Mountains and is found in the Terme Stream.

Diagnosis of $S$. fahrettini from other salmonids was described in Turan et al., (2020). In the present study, the general coloration of freshly preserved specimens silvery on back and flank, yellowish on the belly. There is one small black spot in the postorbital and suborbital areas, approximately equal to the pupil. Red spots numerous, ocellated, organized in four to six irregular longitudinal rows on the median part of the body and half of lower part of the flank. The number of black and red spots on flanks increases with increasing size. Morphological characteristics are compatible with Turan et al. (2020). The minimum and maximum total lengths are 63-241 mm, 
standard length range in Turan et al. (2020) is 136-232 mm in males and $138-172 \mathrm{~mm}$ in females. It is observed that the individual with the smallest standard length among the samples caught in this study is also $49 \mathrm{~mm}$. Turan et al. (2020) were stated the smallest length as $136 \mathrm{~mm}$ in standard length. Also, the results presented in this study show isometric growth for $S$. fahrettini. Thus, phenotypic differences and similarities between different locations of the same species can be evaluated in future studies. It is a really important point to determine the phenotypic variation caused by environmental factors (Cadrin, 2000; Özpiçak \& Polat, 2019; Endo \& Watanabe, 2020; Dunn et al., 2020).

In the literature, there is no study about both morphological characteristics and total length relationships and growth parameters of S. fahrettini. Though, Alp and Kara (2004) found isometric growth for $S$. trutta macrostigma, Y1ldiz (2019) found negative allometric growth for $S$. coruhensis from Artvin Province. The differences between growth can be explained by ecological parameters. Environmental conditions have an important influence on the ecology of fishes and are considered to be the principal factors in intraspecific and interspecific growth differences (Oliveira et al., 2002).

We emphasize that both mitochondrial and nuclear sequence data were used together in the present study. Combine mitochondrial, nuclear sequence and morphometric data will produce much more accurate results in the studies. Especially, evaluating morphological data in more than one region rather than a single gene region together systematics and phylogenetic relationships are complex, will prevent confusion. In this study, a new record, S. fahrettini, from Black Sea Region (TermeSalıpazar1) were described with molecular and morphometric analysis together. However, present study will enable to ichthyologists in planning conservation strategies for $S$. fahrettini from Terme Stream.

\section{ACKNOWLEDGMENTS}

This study was financially supported by Ondokuz Mayıs University (Project No: PYO.FEN.1901.18.009).

\section{REFERENCES}

Alp, A. \& Kara, C. (2004). Length, weight and condition factors of the native brown trouts (Salmo trutta macrostigma Dumeril, 1858 and Salmo platycephalus Behnke, 1968) in the Ceyhan, Seyhan and Euphrates basins. EgeJFAS, 21, 9-15. (Article in Turkish). DOI: 10.12714/egejfas.2004.21.1.5000156960

Bagenal, T.B. \& Tesch, F.W. (1978). Age and growth, in Bagenal T, Methods for assessment of fish production in freshwaters. Blackwell Science Publications, 101-136, Oxford.

Banarescu, P., (1991). Zoogeography of Fresh Waters, Vol. 2. Wiesbaden: AULA-Verlag.

Bardakci, F., Degerli, N., Ozdemir, O. \& Basibuyuk, H.H. (2006). Phylogeography of the Turkish brown trout Salmo trutta L.: mitochondrial DNA PCR-RFLP variation. Journal of Fish Biology, 68(A), 36-55. DOI. 10.1111/j.0022-1112.2006.00948. $\underline{x}$

Bardakci, F., Tanyolac, J., Akpinar, M.A. \& Erdem, U. (1994). Morphological comparison of trout (Salmo trutta L., 1766) populations caught from streams in Sivas. Turkish Journal of Zoology, 18, 1-6.

Behnke, R. J. (1968). A new subgenus and species of trout, Salmo (Platysalmo) platycephalus, from southcentral Turkey, with comments on the classification of the subfamily Salmoninae. Mitt. Hamburg. Zool. Mus. Inst., 66, 1-15.

Bektas, Y., Aksu, I., Kaya, C., Baycelebi, E., Küçük F. \& Turan D. (2020). Molecular systematics and phylogeography of the genus Alburnus Rafinesque, 1820 (Teleostei, Leuciscidae) in Turkey. Mitochondrial DNA Part A, 31(7), 273-284. DOI: 10.1080/24701394.2020.1791840

Bernatchez, L. (2001). The evolutionary history of browntrout (Salmo trutta L.) inferred from phylogeographic, nested clade, and mismatch analyses of mitochondrial DNA variation. Evolution, 55, 351-379. DOI: 10.1111/j.0014-3820.2001.tb01300.x

Bernatchez, L., Guyomard, R. \& Bonhomme, F. (1992). DNA sequence variation of the mitochondrial control region among geographically and morphologically remote European brown trout Salmo trutta populations. Molecular Ecololgy, 1, 161-173. DOI: 10.1111/j.1365-294x.1992.tb00172.x

Berrebi, P., Barucchi, V.C., Splendiani, A., Muracciole, S., Sabatini, A., Palmas, F., Tougard, C., Arculeo, M. \& Marić, S. (2019). Brown trout (Salmo trutta L.) high genetic diversity around the Tyrrhenian Sea as revealed by nuclear and mitochondrial markers. Hydrobiologia, 826(1), 209-231. DOI: 10.1007/s10750-018-3734-5

Cadrin, S.X. (2000). Advances in morphometric identification of fisheries stocks. Reviews in Fish Biology and Fisheries, 10, 91-112.

Chen, H.L., Shen, K.N., Chang, C.W., Iizuka, Y. \& Tzeng, W.N. (2008). Effects of water temperature, salinity and feeding regimes on metamorphosis, growth and otolith Sr: Ca ratios of Megalops cyprinoides leptocephali. Aquatic Biology, 3(1), 41-50. DOI: 10.3354/ab00062

Çiçek, E., Sungur, S. \& Fricke, R., (2020). Freshwater lampreys and fishes of Turkey; a revised and updated annotated checklist 2020. Zootaxa, 4809(2), 241270. DOI: $10.11646 /$ zootaxa.4809.2.2

Cortey, M., \& García-Marín, J.L. (2002). Evidence for phylogeographically informative sequence variation in the mitochondrial control region of Atlantic brown trout. Journal of Fish Biology, 60 (4), 10581063. DOI: 10.1111/j.1095-8649.2002.tb02429.x

Crête-Lafrenière, A., Weir, L.K. \& Bernatchez, L. (2012). Framing the Salmonidae family phylogenetic portrait: a more complete picture from increased 
taxon sampling. PloS ONE, 7 (10), e46662. DOI: 10.1371/journal.pone.0046662

Delling, B., Sabatini, A., Muracciole, S., Tougard, C. \& Berrebi, P. (2020). Morphologic and genetic characterization of Corsican and Sardinian trout with comments on Salmo taxonomy. Knowl Manag Aquat Ecosyst, 421(21). DOI: 10.1051/kmae $/ 2020013$

Dunn, N.R., O'Brien, L.K. \& Closs, G.P. (2020). Phenotypically induced intraspecific variation in the morphological development of wetland and stream Galaxias gollumoides McDowall and Chadderton. Diversity, 12(6), 220. DOI: 10.3390/d12060220

Endo, C. \& Watanabe, K. (2020). Morphological variation associated with trophic niche expansion within a lake population of a benthic fish. PLOS ONE, 15(4), e0232114. DOI: 0.1371/journal.pone.0232114

Felsenstein, J., (1993). Phylogeny Inference Package (PHYLIP). Version 3.5. University of Washington, Seattle.

Guinand, B., Oral, M. \& Tougard, C. (2021). Brown trout phylogenetics: a persistent mirage towards (too) many species. Journal of Fish Biology, 99(2), 298307. DOI: $10.1111 / \mathrm{jfb} .14686$

Guindon, S. \& Gascuel, O. (2003). A simple, fast and accurate method to estimate large phylogenies by maximum-likelihood. Systematic Biology, 52, 696704. DOI: $10.1080 / 10635150390235520$

Gür, H. (2016). The Anatolian diagonal revisited: Testing the ecological basis of a biogeographic boundary. Zoology in the Middle East, 62(3), 189-199. DOI: 10.1080/09397140.2016.1226544

Hall, T.A. (1999). BioEdit: a user-friendly biological sequence alignment editor and analysis program for Windows 95/98/NT. Nucleic Acids Symposium Series, 41, 95-98.

Hewitt, G.M. (2004). The structure of biodiversity-insights from molecular phylogeography. Frontier in Zoology, 1(1), 1-16. DOI: 10.1186/1742-9994-1-4

Huson, D.H. \& Bryant, D. (2006). Application of phylogenetic networks in evolutionary studies. Molecular Biology and Evolution, 23, 254-267. DOI: 10.1093/molbev/msj030

Kalayci, G., Ozturk, R.C., Capkin, E. \& Altinok, I. (2018). Genetic and molecular evidence that brown trout Salmo trutta belonging to the Danubian lineage are a single biological species. Journal of Fish Biology, 93(5), 792-804. DOI: 10.1111/jfb.13777

Kanjuh, T., Marić, A., Piria, M., Špelić, I., Maguire, I. \& Simonović, P. (2020). Diversity of brown trout, Salmo trutta (Actinopterygii: Salmoniformes: Salmonidae), in the danube river basin of croatia revealed by mitochondrial DNA. DOI: 10.3750/AIEP/02939 Acta Ichthyologica et Piscatoria, 50(3), 291-300.

Kottelat, M. (1997). European freshwater fishes: a heuristic checklist of the frshwater fishes of Europe (exclusive of former USSR), with an introduction for nonsystematists and comments on nomenclature and conservation. Biologia, 52, 1-271.

Kottelat, M. \& Freyhof, J. (2007). Handbook of European freshwater fishes. Kottelat, Cornol and Freyhof, Berlin, $646 \mathrm{p}$
Li, D., Kang, D., Yin, Q., Sun, X. \& Liang, L. (2007). Microsatellite DNA marker analysis of genetic diversity in wild common carp (Cyprinus carpio L.) populations. Journal of Genetics and Genomics, 34, 984-993. DOI: 10.1016/S1673-8527(07)60111-8

Librado, P. \& Rozas, J. (2009). DnaSP v.5: A software for comprehensive analysis for DNA polymorphism data. Bioinformatics, 25, 1451-1452. DOI: 10.1093/bioinformatics/btp187

Loy, A., Ciccotti, E., Ferrucci L. \& Cataudella, S. (1996). An application of automated feature extraction and geometric morphometrics: temperature-related changes in body form of Cyprinus carpio juveniles. Aquacultural Engineering, 15(4), 301-311.

Mangit, F. \& Yerli, S.V. (2018). Systematic evaluation of the genus Alburnus (Cyprinidae) with description of a new species. Hydrobiologia, 807, 297-312. DOI: 10.1007/s10750-017-3405-y

Mayr, E. (1942). Systematics and the origin of species. New York: Columbia University Press.

Mohadasi, M., Eagderi, S., Shabanipour, N., Hosseinzadeh, M.S., AnvariFar, H. \& Khaefi, R. (2014). Allometric body shape changes and morphological differentiation of Shemaya, Alburnus chalcoides (Guldenstadf, 1772), populations in the southern part of Caspian Sea using Elliptic Fourier analysis. $\quad I J A B, \quad 2(3), \quad 164-171 . \quad$ DOI: 10.22034/ijab.v2i3.80

Ninua, L., Tarkhnishvili, D. \& Gvazava, E. (2018). Phylogeography and taxonomic status of trout and salmon from the Ponto-Caspian drainages, with inferences on European Brown Trout evolution and taxonomy. Ecology and Evolution, 8, 2645-2658. DOI: $10.1002 /$ ece 3.3884

Oliveira, J.M., Ferreira, A.P. \& Ferreira, M.T. (2002). Intrabasin variations in age and growth of Barbus bocagei populations. Journal of Applied Ichthyology, 18, 134-139. DOI: 10.1046/j.14390426.2002.00333.x

Özen, N. (2013). Molecular phylogeny of brown trouts (Salmo trutta L.) in Turkey. PhD, Adnan Menderes University, Aydın, Turkey.

Özpiçak, M. \& Polat, N. (2019). Determination of genetic structure in Barbus tauricus Kessler, 1877 populations inhabiting a few streams along the Black Sea Region (Turkey) inferred from mtDNA Cytochrome b gene sequence analysis. EgeJFAS, 36(1), 1-11. DOI: 10.12714/egejfas.2019.36.1.01

Pakkasmaa, S. \& Piironen, J. (2000). Water velocity shapes juvenile salmonids. Evolutionary Ecology, 14, 721730. DOI: 10.1023/A:1011691810801

Perea, S., Böhme, M., Zupančič, P., Freyhof, J., Šanda, R., Özuluğ, M., Abdoli, A. \& Doadrio, I. (2010). Phylogenetic relationships and biogeographical patterns in Circum-Mediterranean subfamily Leuciscinae (Teleostei, Cyprinidae) inferred from both mitochondrial and nuclear data. $B M C$ Evolutionary Biology, 10(1), 1-27. DOI: 10.1186/1471-2148-10-265

Posada, D. (2008). jModelTest: Phylogenetic Model Averaging. Molecular Biology and Evolution, 25, 1253-1256. DOI: 10.1093/molbev/msn083 
Pustovrh, G., Snoj, A., \& Bajec, S.S. (2014). Molecular phylogeny of Salmo of the western Balkans, based upon multiple nuclear loci. Genetics Selection Evolution, 46(1), 1-12. DOI: 10.1186/1297-968646-7

Rossi, A.R., Petrosino, G., Milana, V., Martinoli, M., Rakaj, A. \& Tancioni L. (2019). Genetic identification of native populations of Mediterranean brown trout Salmo trutta L. complex (Osteichthyes: Salmonidae) in central Italy. The European Zoological Journal, 86(1), 424-431. DOI: 10.1080/24750263.2019.1686077

Şengör, A.M.C., Altiner, D., Cin, A., Ustaomer, T. \& Hsu, K. J. (1998). Origin and assembly of the Tethyside orogenic collage at the expence of Gondwana Land. In Gondwana and Tethys (Audley-Charles MG, Hallam, A, eds), New York: Oxford University Press.

Segherloo, I. H., Freyhof, J., Berrebi, P., Ferchaud, A. L., Geiger, M., Laroche, J., Levin, B. A., Normandeau, E. \& Bernatchez, L. (2021). A Genomic Perspective on an Old Question: Salmo trouts or Salmo trutta (Teleostei: Salmonidae)? Molecular Phylogenetics and Evolution, 2021, e107204. DOI: 10.1016/j.ympev.2021.107204

Splendiani, A., Palmas, F., Sabatini, A., \& Caputo Barucchi, V. (2019). The name of the trout: considerations on the taxonomic status of the Salmo trutta L., 1758 complex (Osteichthyes: Salmonidae) in Italy. The European Zoological Journal, 86(1), 432-442. DOI: 10.1080/24750263.2019.1686544

Sušnik, S., Knizhin, I., Snoj, A. \& Weiss, S. (2006). Genetic and morphological characterization of a Lake Ohrid endemic, Salmo (Acantholingua) ohridanus with a comparison to sympatric Salmo trutta. Journal of Fish Biology, 68, 2-23. DOI: 10.1111/j.00221112.2006.00902.x

Swofford, D.L., (2003). PAUP: Phylogenetic analysis using parsimony (and other methods) Sunderland, MA: Sinauer Associates.

Tamura, K., Peterson, D., Peterson, N., Stecher, G., Nei, M. \& Kumar, S. (2011). MEGA5: molecular evolutionary genetics analysis using maximum likelihood, evolutionary distance, and maximum parsimony methods. Molecular Biology and Evolution, 28, 2731-2739. DOI: 10.1093/molbev/msr121

Tougard, C., Justy, F., Guinand, B., Douzery, E.J. \& Berrebi, P. (2018). Salmo macrostigma (Teleostei, Salmonidae): nothing more than a brown trout $(S$. trutta) lineage? Journal of Fish Biology, 93, 302310. DOI: $10.1111 / \mathrm{jfb} .13751$

Turan, D., Kottelat, M. \& Engin, S. (2014a). Two new species of trouts from the Euphrates drainage, Turkey (Teleostei: Salmonidae). Ichthyological Exploration of Freshwaters, 24(3), 275-287.

Turan, D., Dogan, E., Kaya, C. \& Kanyılmaz, M. (2014b). Salmo kottelati, a new species of trout from Alakır stream, draining to the Mediterranean in southern Anatolia, Turkey (Teleostei, Salmonidae). Zookeys, 462, 135-151. DOI: 10.3897/zookeys.462.8177

Turan, D., Kalaycı, G., Bektaş, Y., Kaya, C. \& Baycelebi, E. (2020). A new species of trout from the northern drainages of Euphrates River, Turkey (Salmoniformes: Salmonidae). Journal of Fish Biology, 96(6), 1454-1462. DOI: 10.1111/jfb.14321

Turan, D., Kottelat, M., \& Engin, S. (2009). Two new species of trouts, resident and migratory, sympatric in streams of northern Anatolia (Salmoniformes: Salmonidae). Ichthyological Exploration of Freshwaters, 20(4), 333-364.

Turan, D., Kottelat, M. \& Kaya C. (2017). Salmo munzuricus, a new species of trout from the Euphrates River drainage, Turkey (Teleostei: Salmonidae). Ichthyological Exploration of Freshwaters, 28(1), 55-63.

Turan, D.T., \& Bayçelebi, E. (2020). First Record of Salmo pelagonicus Karaman, 1938 (Teleostei: Salmonidae) in the Karamenderes River, Turkey. JAES, 5(4), 551555. DOI: $10.35229 /$ jaes.777776

Uncu, L. (1995). Terme Çayı ile Kocamandere Havzalarında Fiziki Coğrafya Araştırmalar ve Doğal Çevre Sorunları. Yüksek Lisans Tezi, Ankara Üniversitesi Sosyal Bilimler Enstitüsü, Ankara.

Von Schalburg, K.R., Yazawa, R., De Boer, J., Lubieniecki, K.P., Goh, B. \& Straub, C.A., Koop B.F. (2008). Isolation, characterization and comparison of Atlantic and Chinook salmon growth hormone 1 and 2. BMC Genomics, 9(1), 1-12. DOI: 10.1186/1471-2164-9-522

Yıldız, R. (2019). Sagittal otolith biometry of Çoruh trout (Salmo coruhensis Turan, Kottelat and Engin, 2010) inhabiting Çam Stream (Artvin, Turkey). Msc, Ondokuz Mayıs University, Samsun, Turkey. 